\title{
Questes
}

\section{Simone Roux, Paris au Moyen Âge, Paris, Hachette Littératures, 2003 (coll. La vie quotidienne).}

\section{Mickaël Wilmart}

\section{Q OpenEdition \\ 1 Journals}

\section{Édition électronique}

URL : http://journals.openedition.org/questes/1767

DOI : 10.4000/questes. 1767

ISSN : 2109-9472

Éditeur

Les Amis de Questes

\section{Édition imprimée}

Date de publication : 15 mai 2003

Pagination : 24-25

ISSN : 2102-7188

\section{Référence électronique}

Mickaël Wilmart, «Simone Roux, Paris au Moyen Âge, Paris, Hachette Littératures, 2003 (coll. La vie quotidienne). », Questes [En ligne], 4 | 2003, mis en ligne le 01 janvier 2014, consulté le 25 septembre 2020. URL : http://journals.openedition.org/questes/1767 ; DOI : https://doi.org/10.4000/questes. 1767

Ce document a été généré automatiquement le 25 septembre 2020.

(C) Association des amis de «Questes » 


\section{Simone Roux, Paris au Moyen Âge, Paris, Hachette Littératures, 2003 (coll. La vie quotidienne).}

Mickaël Wilmart

\section{RÉFÉRENCE}

Simone Roux, Paris au Moyen Âge, Paris, Hachette Littératures, coll. « La vie quotidienne », 2003

\section{NOTE DE L'ÉDITEUR}

Cet article n'a pas encore fait l'objet d'une autorisation de publication. 